\title{
Studies on Negative Chemotaxis and the Survival Value of Motility in Pseudomonas fuorescens
}

\author{
By J. L. SMITH AND R. N. DOETSCH \\ Department of Microbiology, University of Maryland, \\ College Park, Maryland 20742, U.S.A.
}

(Accepted for publication 3I October I968)

SUMMARY

Multiplication of aerobic piliated $\mathrm{fla}^{+}$and $\mathrm{fla}^{-}$Pseudomonas fuorescens growing in aerated mixed culture gave $\mathrm{fla}^{+}: \mathrm{fla}^{-}$ratios approximately $\mathbf{I}: \mathbf{I}$ over a $24 \mathrm{hr}$ growth period. When $\mathrm{fla}^{+}$and $\mathrm{fla}^{-}$were cultured simultaneously in non-aerated media, fla ${ }^{+}$then outgrew the fla- mutant to a final $(24 \mathrm{hr})$ ratio of $10: I$ or greater, thereby lending supporting evidence to the view that motility is a survival factor in environments where 'nutrients' are limited or discontinuous.

Gravity, magnetism, and light did not influence a negative chemotactic response of $\mathrm{fla}^{+} \boldsymbol{P}$. fluorescens to hydrogen ions. Temperature variations, $\mathrm{pH}$, or viscosity alterations either inhibited or stimulated motility, thereby making impossible a determination of their specific effects. Various antibiotics, membrane-active agents, and protein or DNA synthesis inhibitors were employed in attempts to interfere with the chemotactic response, but none completely inhibited chemotaxis without also affecting motility. The cytoplasmic membrane may act as a transducer of environmental stimuli in chemotaxis.

\section{INTRODUCTION}

The positive value of motility as a survival factor for bacteria in environments where 'nutrients' or 'harmful agents' are discontinuously distributed seems fairly obvious; however, little verification of this view exists outside of a few theoretical speculations. Carlson (1962) suggested that no matter how inefficient the motility mechanism, an organism could always achieve a net gain in collection of nutrients by moving. Piliation also is reported to favour survival of aerobic bacteria by allowing surface film formation in static cultures (Brinton, 1959). The experimental results presented here were obtained from a study on a system wherein the factor favouring multiplication was oxygen, which has long been known to invoke an aerotactic response in several kinds of bacteria including Pseudomonas (Beijerinck, 1893; Baracchini \& Sherris, 1959).

Tactic responses involve not only mechanisms by which bacteria move, but imply the (possible) existence of sensing and transducing devices which direct bacteria towards conditions most suitable for survival and multiplication (Doetsch \& Hageage, I968).

Little in the way of postulated mechanisms of tactic responses has been published for bacterial systems. Links (1955) maintained that any factor which can suddenly and reversibly increase the quantity or consumption of energy-supplying substance 
to the motor apparatus can exercise a chemotactic effect. Clayton (I958) modified Links's hypothesis and proposed that the phototaxis in Rhodospirillum rubrum involved an ATP-mediated reaction closely associated with photosynthetic phosphorylation.

Recently Armstrong, Adler \& Dahl (1967) isolated non-chemotactic mutants of Escherichia coli, but were unable to determine the reason for the lack of chemotactic activity.

Hydrogen ions, which stimulate negative chemotaxis in fla ${ }^{+}$Pseudomonas fluorescens, provide a means for investigation which is rapid, repeatable, and simple (Smith \& Doetsch, 1968). The present paper reports experiments attempting to uncover the basis of this negative chemotactic response. In our view, 'negative chemotaxis' is characterized by an abrupt change in the direction of translational motility. This behaviour is postulated to be caused by a critical change in the membrane potential (the membrane serving as a non-specific environmental monitor) when a bacterium encounters a chemical stimulus. The energy of such stimuli is transduced into a signal causing a reversal in direction of flagellar motion. A mechanism whereby this might be accomplished has been suggested by Doetsch \& Hageage (1968). All chemotactic responses by bacteria may thus be considered movements away from environmental conditions which induce a critical change in membrane potential.

\section{METHODS}

Bacteria studied. Pseudomonas fuorescens (University of Maryland 40I), an obligately aerobic, actively motile bacterium (fla ${ }^{+}$) with a single polar flagellum approximately $5 \mu$ long was selected for this investigation.

Mutant isolation. Non-motile (fla-) mutants were obtained by a method similar to that of Armstrong et al. (1967) by growing the fla ${ }^{+}$organisms at $30^{\circ}$ in $10 \mathrm{ml}$. Trypticase Soy Broth (TSB) (Baltimore Biological Laboratories, Baltimore, Md., U.S.A.) overnight, inoculating one loopful of culture on to the centre of a Tryptone Semisolid Agar (TSSA) (Difco Laboratories, Detroit, Mich., U.S.A.) plate prepared with I \% (w/v) Bacto-Tryptone and $0.35 \%$ (w/v) Bacto-Agar. Plates were sealed with masking tape to prevent drying and incubated overnight at $30^{\circ}$. Growth was harvested daily with a Pasteur pipette from the centre of the large colony which developed, and washed once in $3 \mathrm{ml}$. TSB; one loopful of this suspension then was used to inoculate a fresh TSSA plate. The procedure was repeated successively for Io days at which time the suspension was streaked on to several Trypticase Soy Agar (TSA) (Baltimore Biological Laboratories) plates for colony development and isolation. These plates were incubated $24 \mathrm{hr}$ at $30^{\circ}$, colonies were picked and each inoculated by stabbing into tubes containing Io ml. Sulfide Indole Motility (SIM) medium (Difco Laboratories). After overnight incubation at $30^{\circ}$, the tubes were examined for the presence of non-motile isolates. These were checked for: Gram-negative staining reaction (Hucker), formation of small (I mm. diameter) colonies on TSSA, growth in phenol-red + sucrose broth (Difco), weak acidic reaction in dextrose + phenol-red broth (Difco), basic reaction in litmus milk (Difco), nitrate reduction, inability to liquefy gelatin, presence of cytochrome oxidase using Taxos N Neisseria-Pseudomonas detection discs (Baltimore Biological Laboratories), and a growth rate in TSB comparable to the parent strain. All tests requiring incubation were made at $30^{\circ}$ for $24 \mathrm{hr}$. The mutant chosen formed 
small ( $\mathrm{I} \mathrm{mm}$.), shiny, discrete colonies on TSA spread plates, whereas the parent strain formed larger, less opaque, colonies on the same medium. $O$ antiserum prepared in rabbits against the $\mathrm{fla}^{-}$isolate was tested against the parent $\mathrm{fla}^{+}$strain and gave a positive rapid slide agglutination test reaction. When stained by Rhodes (1958) method, the mutant was non-flagellated. Both cultures had polar Type VI pili when grown I6-18 $\mathrm{hr}$ at $30^{\circ}$ in TSB and stained with I \% (w/v) sodium phosphotungstate $(\mathrm{pH} 7.0)$ on carbon-formvar coated copper grids and examined with an electron microscope (RCA EMU 3 f).

\section{Selection experiments}

Culture preparation. $\mathrm{Fla}^{+}$and $\mathrm{fla}^{-}$cultures were grown $\mathrm{I} 6-\mathrm{I} 8 \mathrm{hr}$ at $25^{\circ}$ in $100 \mathrm{ml}$. TSB contained in $150 \mathrm{ml}$. prescription bottles. Forty $\mathrm{ml}$. of each culture were removed and aseptically washed twice in TSB after centrifuging at $2000 \mathrm{~g}$ for $15 \mathrm{~min}$. each washing. Each suspension was adjusted with TSB to a $\mathrm{I} \cdot 0$ absorbance at $425 \mathrm{~m} \mu$.

Determination of survival. $\mathrm{Fla}^{+}$and fla- cultures were distributed into five $250 \mathrm{ml}$. cotton-stoppered sidearm flasks containing $100 \mathrm{ml}$. TSB in the following manner: flask I, $2 \mathrm{ml}$. fla ${ }^{+}$suspension; flask $2,2 \mathrm{ml}$. fla- suspension; flasks 3,4 and 5 contained I $\mathrm{ml}$. $\mathrm{fla}^{+}$and $\mathrm{I} \mathrm{ml}$. fla ${ }^{-}$. Flasks $\mathrm{I}, 2$ and 3 were shaken at $20 \mathrm{rev}$. $/ \mathrm{min}$. on an incubatorshaker at $30^{\circ}$, and flasks 4 and 5 were incubated without shaking. Colony counts were made from flasks 3,4 and 5 after 8 and $24 \mathrm{hr}$ by spreading $0.1 \mathrm{ml}$. of a diluted suspension on to TSA plates which had been dried overnight at $37^{\circ}$, then incubated at $30^{\circ}$ for $24 \mathrm{hr}$. Multiplication of the culture also was followed by measuring absorbance of flasks I and 2 for $8 \mathrm{hr}$ at $425 \mathrm{~m} \mu$. Flasks 4 and 5 were not shaken except for sampling, each being sampled only once to minimize any effect shaking would have on the results if only a single flask were used. After $24 \mathrm{hr}$ incubation at $30^{\circ}$ on TSA spread plates, $\mathrm{fla}^{+}: \mathrm{fla}^{-}$ratios at the different time intervals tested were determined.

\section{Chemotaxis experiments}

Culture preparation. Forty $\mathrm{ml}$. of a $\mathrm{fla}^{+}$Pseudomonas fluorescens culture grown in $100 \mathrm{ml}$. TSB in a $150 \mathrm{ml}$. prescription bottle for $16-18 \mathrm{hr}$ at $30^{\circ}$ were washed once in $\mathrm{pH} 7.0$ buffer (modified from Adler, $1966 \mathrm{~b}$ ), and resuspended to the original volume to give an absorbance of 0.25 at $425 \mathrm{~m} \mu$ or approximately $3.0 \times 10^{8}$ bacteria $/ \mathrm{ml}$. The buffer consisted of $10^{-2} \mathrm{M}$-mono- and di-basic $\mathrm{K}$ phosphates, $\mathrm{IO}^{-3} \mathrm{M}-\mathrm{MgSO}_{4}$ and $\mathrm{IO}^{-4} \mathrm{M}$-EDTA. When chemicals were added to the buffer, this was done first and then drops of a dense suspension of bacteria $(50 \mathrm{ml}$. washed as previously described and resuspended to $3 \mathrm{ml}$.) were added with a Pasteur pipette to give the above-mentioned absorbancy.

Flat glass capillary preparation. Flat glass capillaries prepared from $8 \mathrm{~mm}$. internal diameter flint-glass tubing segments by the method of Wright \& Colebrook (I92I) were cut to $4 \mathrm{~cm}$. lengths. Approximate inside dimensions were $\mathrm{I} \cdot 2 \mathrm{~mm}$. wide by $0.3 \mathrm{~mm}$. deep.

Demonstration of negative chemotaxis. Capillary tubes were filled from Pasteur pipettes containing the test suspension; one end was plunged twice into plain $(1 \cdot 5 \%$ w/v) 'Ionagar' (Oxoid) No. 2 (Consolidated Laboratories, Inc., Chicago, Ill.) so that a $\mathrm{I} \mathrm{cm}$. length agar plug was formed; the other end was plunged once into either acidic Ionagar (titrated to $\mathrm{pH} \mathrm{r} \cdot 0$ at $55^{\circ}$ with $\mathrm{N}-\mathrm{HCl}$ ) or basic Ionagar $(\mathrm{pH} 12 \cdot 0$ with $\mathrm{N}-\mathrm{NaOH}$ ), depending upon the experiment done. A bit of 'Vaseline' (Chesebrough Manuf. Co.) was placed at either end of the capillary to allow secure mounting on a glass 
slide (Fig. I). Observations were made with a Bausch \& Lomb Stereozoom Variable Power microscope, utilizing the substage concave mirror and a Nicholas Variable Illuminator mounted in the substage lamp receptacle. The mirror was adjusted to give a 'dark-field' effect. Using an ocular micrometer, calibrated to read directly in $\mathrm{mm}$. for different magnifications, formation and migration of bacterial 'acid response bands' (a.r.b.) or basic response bands (b.r.b.) were observed and recorded as $\mu \mathrm{m}$. moved per unit time. Active motility of suspensions sealed in capillary tubes for $3 \mathrm{hr}$ revealed that oxygen depletion would not be a factor affecting these experiments during the $30 \mathrm{~min}$. experimental time period. (The fla ${ }^{+}$Pseudomonas fluorescens used here is aerotactic and motility ceased rapidly in very dense suspensions held under conditions of limited aeration.)

Measurement of motility. Motility estimates made by the method of Shoesmith (I960) were based on bright-phase observation of wet-mount preparations examined with a Zeiss photomicroscope equipped with $\times 12.5$ oculars and a $\times 63$ Neofluar phase objective. The right eyepiece was fitted with a black cardboard diaphragm with a centre opening I mm. in diameter. Motility of the suspensions was estimated by counting the number of organisms swimming by the aperture during a I min. interval. An average of five observations was used to estimate the 'per cent motile' for any given sample.

\section{Investigations of factors possibly influencing acid response bands}

Temperature. Washed suspensions were divided into $3 \mathrm{ml}$. portions and incubated $30 \mathrm{~min}$. at $4^{\circ}, 20^{\circ}$ and $37^{\circ}$. Acid response band formation and migration then were followed for $30 \mathrm{~min}$. after capillary tubes were prepared in triplicate on glass slides. Experiments were made in $4^{\circ}$ and $37^{\circ}$ incubators and at room temperature $\left(\cong 20^{\circ}\right)$, and where appropriate, a rapid visual estimation of motility was made.

Magnetic fields. Washed bacterial suspensions in the process of forming a.r.b. were subjected to the effect of a 12,000 gauss horseshoe magnet (Alnico $V$ ) to determine the influence of a strong non-fluctuating magnetic field on it. Capillary tubes prepared in triplicate were placed both parallel and at right angles to the lines of force and at both the north and south poles. Capillary tubes parallel to lines of force were positioned with one end of the tube touching the magnetic pole, whereas tubes at right angles to the lines of force were placed with the centre $5 \mathrm{~mm}$. from one of the poles. Migration of a.r.b. was followed for a period of $30 \mathrm{~min}$. The effect of a fluctuating magnetic field was observed by placing the capillary tube preparation on the centre of the platform of a Mag-mix magnetic stirrer, Model I I-V-3 (Precision Scientific Co., Chicago, Ill.). The capillaries were mounted $3 \mathrm{~mm}$. above the surface of the platform to obviate any effects of heat generated by the stirrer motor. The dissecting microscope optical system was mounted above the platform so the a.r.b. migration could be followed, and a Nicholas Illuminator was mounted on the adjustable lamp base. The slide preparation was positioned so that the centre of the capillary tubes was at the centre of rotation of the magnetic stirrer. Migration of a.r.b when viewed from above was from left to right; the stirrer rotation was counterclockwise. Migration of a.r.b. formed was followed for $30 \mathrm{~min}$. with the stirrer set at maximum output.

Gravity. Migration rates were determined in triplicate capillary tubes by mounting the slide preparations (I) in a horizontal position, (2) with the a.r.b. ascending, and (3) with the a.r.b. descending. 
Viscosity. Buffered solutions ( $\mathrm{pH}_{7}$ ) of polyvinylpyrrolidone, (type NPJ-K 90:PVP) and Carbowax 4000 , both $5 \%(w / v)$, were tested for their ability to affect band formation and motility rate. Relative viscosity of each solution and the buffer was measured by noting the time necessary for the meniscus of the solution to drop a $4 \mathrm{~cm}$. length in a vertically held Pasteur pipette.

Light. Capillary tubes again were prepared in triplicate. Migration rates were plotted in unfiltered light using the Nicholas Illuminator at full brightness $(35 \mathrm{~W}$.) and in the dark, except for brief illumination of the specimen so that readings could be made at 5 min. intervals. Wratten gelatin filters were mounted on a transparent glass

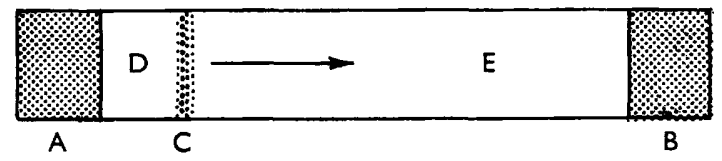

Fig. I. Diagram of capillary tube experiment. $A=$ acidic agar plug, $B=$ plain Ionagar plug, $C=A R B, D=$ zone of non-motile organisms, and $E=$ motile organisms.

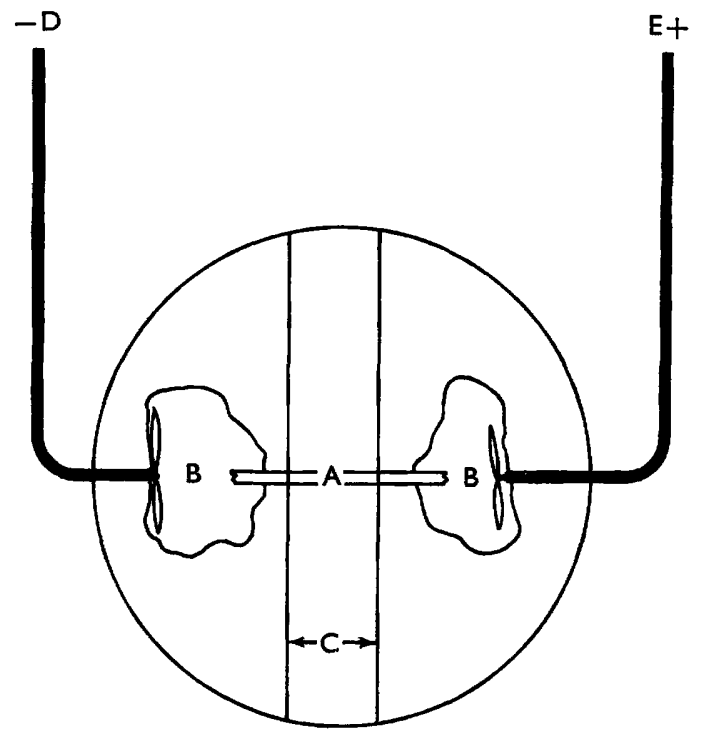

Fig. 2. 'Grid' used to measure effect of direct electric current on bacterial cells and acid response bands. $A=$ capillary tube, $B=$ saline agar, $C=3 \mathrm{~cm}$. space cut in plastic Petri dish, $\mathbf{D}=$ cathode, and $\mathrm{E}=$ anode.

microscope stage; the capillary preparation then was placed on top of the filter. Formation and migration of a.r.b. was compared for $30 \mathrm{~min}$. against the same experiment done in a darkroom. Wratten filters no. 58 (green, dominant wavelength $540.2 \mathrm{~m} \mu$ ), no. 25 (red, 6I 5. I m $\mu$ ), no. I 5 (yellow, 579.3 $\mathrm{m} \mu$ ), and no. 47 (blue, $463.7 \mathrm{~m} \mu$ ) were used.

Direct electric current. A Thomas Electrophoresis Unit, Model no. 2I, was attached to a 'grid' of the design shown in Fig. 2. Capillary tubes were placed on the grid and saline agar $(\mathrm{I} \%, \mathrm{w} / \mathrm{v}, \mathrm{NaCl})$ was dropped on each end to ensure electrical contact with the electrodes. The voltage necessary to cause migration of heat-killed ( $60^{\circ}$ for $15 \mathrm{~min}$.) 
bacteria was determined in cell suspensions in buffers of $\mathrm{pH} 5,7$ and 8 using Ionagar of $\mathrm{pH} 7.0$ as capillary plugs. Ionagar plugs of $\mathrm{pH} \mathrm{I}$ and 8 were used in the anode side of the capillary when the voltage necessary to disrupt any a.r.b. which formed in response to each type of plug was determined. Voltage necessary to cause migration of heatkilled bacteria with a pH I acid agar plug also was determined.

Influence of $p H$. Demonstration of the applicability of Weber's Law to negative chemotaxis was attempted by suspending washed bacteria in buffer adjusted to $\mathrm{pH}$ values of $5,6,7$ and 8 , and determining the reaction of each suspension to Ionagar plugs of $\mathrm{pH} \mathrm{1,} \mathrm{2,} 3$ and 4. Pseudomonas fluorescens grown in bottles of TSB (100 ml.) at $\mathrm{pH} 6,7$ and 8 were washed and suspended in $\mathrm{pH} 7$ buffer and judged for their ability to form a.r.b to agar plugs of $\mathrm{pH} 1,2,3$ and 4 .

\section{Table I. Compounds tested for their effect on acid response bands and motility}

Compound

Dicoumarol

Eserine $\mathrm{SO}_{4}$

Acetylcholine $\mathrm{Cl}$

Atabrine

Indole acetic acid

Sodium dodecyl SO.

Dimethyl sulphoxide (DMSO)

Cetylpyridinium $\mathrm{Cl}$

DL-p-Fluorophenylalanine

Urea

Sodium barbital

Morphine $\mathrm{SO}_{4}$

Cocaine $\mathrm{SO}_{4}$

Sanguinarine $\mathrm{SO}_{4}$

Amobarbital

\section{Compound}

Chloramphenicol

'Triton'

Benzalkonium $\mathrm{Cl}$

p-Nitrophenyl glycerol (PNPG)

Potassium cyanide

Polymyxin B SO,

Phenethyl alcohol

n-Butanol

Tyrocidine $\mathrm{HCl}$

Digitonin

Serotonin creatinine $\mathrm{SO}_{4}$

Bacitracin

Strychnine $\mathrm{SO}_{4}$

Pentachlorophenol

p-Chloromercuribenzoate

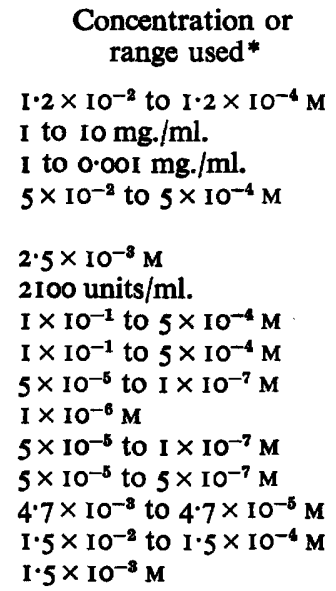

Concentration or $1.2 \times 10^{-2}$ to $\mathrm{I} \cdot 2 \times 10^{-4} \mathrm{M}$ I to $10 \mathrm{mg} . / \mathrm{ml}$. I to $0.001 \mathrm{mg} . / \mathrm{ml}$. $5 \times 10^{-2}$ to $5 \times 10^{-4} \mathrm{M}$

* When a range of concentrations was tested, the increments were $0.5 \mathrm{M}$ or $0.5 \mathrm{mg} . / \mathrm{ml}$.

Chemical agents. Various compounds reported to be inhibitors of nerve impulse transmission in 'higher' organisms, DNA- and protein synthesis inhibitors, and materials able to destroy membrane integrity were incorporated into the buffer system at various concentrations. Compounds such as dimethyl sulphoxide (DMSO) also were used if they showed some promise from reports of effects on other organisms. Concentrations are given in Table $\mathrm{I}$.

Each compound was screened for ability to inhibit a.r.b. formation, and if any was noted it was further checked to determine its effect on motility as compared with a control of plain buffer. Any compounds which showed little effect on motility and that seemed at the same time to affect a.r.b. formation were studied further.

Several compounds were tested for activity in the presence of non-inhibitory amounts of buffered $(\mathrm{pH} 7)$ DMSO $(0.0312 \mathrm{M})$ to see whether permeability and, hence, the action of these compounds, was intensified. All compounds were prepared in buffer in as small an amount as possible on the same day they were tested. Solid compounds were weighed and dissolved in $3 \mathrm{ml}$. buffer for the desired concentration; dilutions of fluid compounds were made to the desired concentration in buffer, $3 \mathrm{ml}$. of which was 
used as a test sample in the experiment. Bacteria were added only after the dissolution of the solid material, and the mixtures were allowed to incubate at room temperature $\left(20^{\circ}\right)$ in the solutions for $30 \mathrm{~min}$. before any experiment was performed.

\section{RESULTS AND DISCUSSION}

Selection experiments

The ratio of $\mathrm{fla}^{+}: \mathrm{fla}^{-}$organisms remained constant when they were grown together as mixed aerated cultures, fla- colony counts being always slightly higher than fla ${ }^{+}$counts

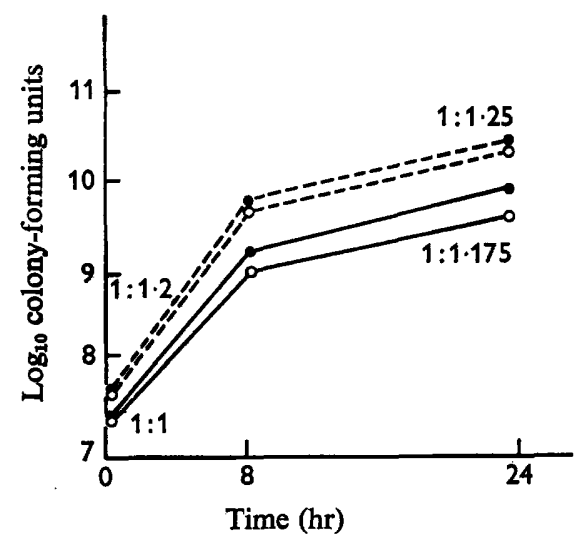

Fig. 3

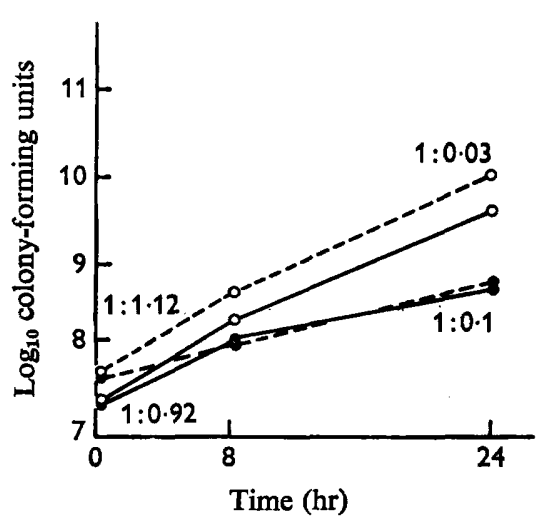

Fig. 4

Fig. 3. Multiplication of $\mathrm{fla}^{+}$and fla-Pseudomonas fuorescens over a $24 \mathrm{hr}$ period in two different experiments; showing $\mathrm{fla}^{+}: \mathrm{fla}^{-}$ratios in aerated mixed cultures. $\mathrm{O}, \mathrm{fl}^{+} ; \boldsymbol{O}, \mathrm{fla}^{-}$. -, Expt. 1; - - Expt. 2.

Fig. 4. Multiplication of $\mathrm{fla}^{+}$and fla- Pseudomonas fluorescens over a $24 \mathrm{hr}$ period in two different experiments; showing fla ${ }^{+}: \mathrm{fla}^{-}$ratios in non-aerated mixed cultures. $\mathrm{O}, \mathrm{fl}^{+} ; \mathbf{O}, \mathrm{fl}^{-}$. -, Expt. I; - - Expt. 2.

(Fig. 3). Fla $^{+}: \mathrm{fla}^{-}$ratios changed remarkably from a $\mathrm{I}: \mathrm{I}$ ratio in non-aerated media: after $24 \mathrm{hr}$ the fla ${ }^{+}$colony count was I0-33 times greater than the fla- count (Fig. 4).

Selective multiplication of aerobic $\mathrm{fla}^{+}$bacteria under non-aerated conditions supports the view that motility is a positive factor in survival. If a bacterium is living in an environment where favourable conditions are discontinuous or limited it is able to facilitate contact with more satisfactory conditions if it is motile. An actively motile organism could accomplish this in two ways: (I) by migrating through the medium to more favourable areas; and (2) by causing the medium to circulate in the immediate vicinity of the organism. Operation of either factor would enable the organism to increase the amount of material contacting the cell surface, thereby increasing the flux of material across the membrane, and resulting in greater availability of nutrients and dissipation of waste or growth-inhibitory substances present in the medium or secreted by the organism itself. Our data thus agree with Carlson's (1962) analysis since oxygen is a 'nutrient' in the broad sense.

The results demonstrate furthermore that motile piliated bacteria have an advantage over non-motile piliated forms in static (non-aerated) conditions. Although positive 
aerotaxis and piliation admittedly both play a role in survival of aerobic forms, motility is considered the greater advantage under the particular experimental conditions used here since it allows for the expression of this response.

\section{Chemotactic experiments}

Demonstration of negative chemotaxis. $\mathrm{Fla}^{+}$Pseudomonas fluorescens suspensions in capillary tubes developed a single $0.1 \mathrm{~mm}$. deep band in which the bacteria migrated away from the acidic Ionagar plug. The $\mathrm{pH}$ values of plugs tested ranged from less than I.O to $4 \cdot 0$. No band developed at the opposite end of the tube which was plugged

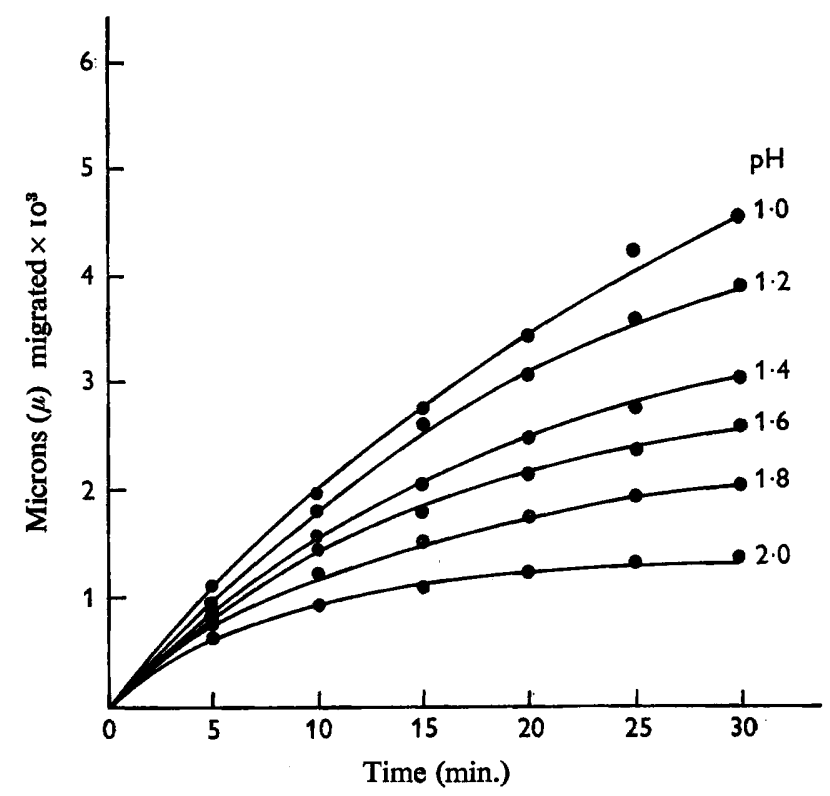

Fig. 5. Migration of acid response bands as related to $\mathrm{pH}$ of acidic Ionagar plug.

with plain Ionagar and served as a control. At $\mathrm{pH} \mathrm{I} \cdot 0$ band migration was as rapid as $200 \mu / \mathrm{min}$. over a period of 30 to $40 \mathrm{~min}$., after which the migration rate then decreased. A sharp boundary was always observed on the side of the band directed to the origin of the stimulus, the opposite side being more diffuse (Plate I). Phasemicroscopic examination $(\times 630)$ of the band showed that bacteria moving to the sharp boundary immediately reversed direction in a manner similar to the 'Schreckbewegung' described by Englemann (I883). Bacteria entering the acid zone became quickly immobilized. Basic response bands formed in reponse to the stimulus from basic agar plugs were not as sharply defined as those in response to acid and therefore were not further considered. An a.r.b. did not develop if either deflagellated (Io $\mathrm{ml}$. suspension exposed for $5 \mathrm{~min}$. at $\mathrm{I} 6,000 \mathrm{rev}$./min. in a Sorvall OmniMixer) or heat-killed $\left(60^{\circ}\right.$ for $15 \mathrm{~min}$.) bacteria were used. Incorporation of $\mathrm{I} \mathrm{mg}$. $/ \mathrm{ml}$. $m$-cresol purple and $10 \mathrm{mg}$. $/ \mathrm{ml}$. bromthymol blue in the buffer revealed that an a.r.b. formed between $\mathrm{pH} 5.5$ and 6.0 , and the organisms therein moved as the acid diffused from the agar plug to always remain in this $\mathrm{pH}$ range, which 
covered a zone approximately $2 \mathrm{~mm}$. wide. Neither dye affected the motility of the organism over at least I hr. A mixture (I:I:I) of Pseudomonas fluorescens, Spirillum serpens and Agrobacterium tumifaciens suspensions gave a single a.r.b. composed of all three organisms migrating as a unit; these organisms are equally sensitive and negatively chemotactic. Microscope examination and electron micrographs revealed that bacteria remaining on the acid side of the retreating band were not motile and lacked flagella. Varying the concentrations of $\mathrm{HCl}$ in Ionagar plugs resulted in response curves in which migration rate was proportional to total distance traversed from the acidic agar plug (Fig. 5). If an acidic agar plug was placed in both ends of a capillary tube, two a.r.b.'s developed which migrated towards each other to disappear immediately upon contact, leaving only non-motile bacteria throughout the tube.

\section{Studies of factors influencing acid response bands}

Temperature. Bacteria incubated at $4^{\circ}$ and then transferred to capillary tubes were non-motile, therefore no a.r.b. was formed. Acid response bands formed at $20^{\circ} \mathrm{mi}$ grated at the same rate as controls, but subsequent tubes set up from that portion of the culture incubated for more than $\mathrm{I}$ hr at $37^{\circ}$ failed to show a.r.b. formation, since the organisms became non-motile because of temperature effects.

Table 2. Effect of direct electric current on heat-killed bacteria and on acid response band of living bacteria

\begin{tabular}{|c|c|c|c|c|c|}
\hline Stimulus & $\begin{array}{c}\text { Cell } \\
\text { condi- } \\
\text { tion* }\end{array}$ & $\begin{array}{c}\text { Buffer } \\
\text { pH }\end{array}$ & $\begin{array}{c}\text { Migration } \\
\text { (units/min.) } \dagger\end{array}$ & $\begin{array}{c}\text { Volts } \\
\text { to movı } \\
\text { cells! }\end{array}$ & $\begin{array}{r}\text { Volts to } \\
\text { disperse } \\
\text { a.r.b. } \$\end{array}$ \\
\hline None & Dead & 5 & . & 10 & No band \\
\hline None & Dead & 7 & . & 7 & No band \\
\hline None & Dead & 8 & . & 10 & No band \\
\hline pH I agar & Dead & 7 & . & IO & No band \\
\hline pH I agar & Live & 5 & . & - & No band \\
\hline pH I agar & Live & 7 & 0.33 & - & 23 \\
\hline pH I agar & Live & 8 & 0.23 & • & $32 \cdot 5$ \\
\hline pH 8 agar & Live & 5 & No band & 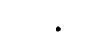 & No band \\
\hline pH 8 agar & Live & 7 & No band & 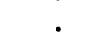 & No band \\
\hline pH 8 agar & Live & 8 & No band & . & No band \\
\hline
\end{tabular}

* Cells in buffer (adjusted to indicated pH by titration of $10^{-2} \mathrm{M}$-phosphate buffer).

$\dagger$ One unit is equal to $0.071 \mathrm{~mm}$. (7I $\mu$ ) on ocular micrometer.

$\ddagger$ Indicates reading on voltmeter of Thomas Electrophoresis Unit when bacteria began migrating towards anode.

$\S$ Indicates reading on voltmeter of Thomas Electrophoresis Unit causing dispersion of acid response band and migration towards anode.

Magnetic fields, gravity, light and age. No effect on a.r.b. was observed in the experiments on magnetic fields, gravity and light. In addition, organisms incubated in TSB for $48 \mathrm{hr}$ and I week gave an a.r.b. similar to that of the $16-\mathrm{r} 8 \mathrm{hr}$ culture.

Viscosity. Comparative rates of flow of the solutions used to test for viscosity were $0.3 \mathrm{sec} . / \mathrm{cm}$. for buffer, $0.4 \mathrm{sec} / \mathrm{cm}$. for $5 \%$ Carbowax, and $6.65 \mathrm{sec} . / \mathrm{cm}$. for $5 \%$ PVP. No band was formed with PVP in the buffer, and the band formed with Carbowax was less dense than that in the buffer control. Motility counts revealed that the reason for these differences lay in somewhat inhibited motility by the more viscous 
solutions. Although motility was not completely halted (motility counts were $14 \%$ of the buffer control in PVP and $72 \%$ in Carbowax), the decrease in the case of PVP was sufficient to completely eliminate band formation.

Direct electric current. Voltage required to cause migration of dead cells towards the anode differed considerably from that required when living organisms were used (Table 2). Migration of dead cells occurred with an input of Io $\mathrm{V}$. whether the acid stimulus was present in the tube or not, whereas at least $23 \mathrm{~V}$. were necessary to cause disruption of a.r.b. moving away from the acid stimulus. As might be expected, no a.r.b. was formed either with dead organisms with or without a stimulus, or with living

Table 3. Effect of varying the $p H$ of the buffer on acid response band formation

$\begin{array}{cccccc}\begin{array}{c}\text { Cell } \\ \begin{array}{c}\text { suspension } \\ \text { pH }^{*}\end{array}\end{array} & \begin{array}{c}\text { Agar } \\ \text { plug } \\ \text { pH } \dagger\end{array} & \begin{array}{c}\text { a.r.b. } \\ \text { forma- } \\ \text { tion } \ddagger\end{array} & \begin{array}{c}\text { Cell } \\ \text { suspension } \\ \text { pH }\end{array} & \begin{array}{c}\text { Agar } \\ \text { plug } \\ \text { pH } \dagger\end{array} & \begin{array}{c}\text { a.r.b. } \\ \text { forma- } \\ \text { tion }\end{array} \\ 5 & \text { I } & +- & 7 & \text { I } & + \\ 5 & 2 & +- & 7 & 2 & + \\ 5 & 2 \cdot 5 & +- & 7 & 2 \cdot 5 & - \\ 5 & 3 & - & 7 & 3 & - \\ 5 & 3 \cdot 5 & - & 7 & 3 \cdot 5 & - \\ 5 & 4 & - & 7 & 4 & - \\ 6 & \text { I } & + & 8 & 1 & + \\ 6 & 2 & + & 8 & 2 & + \\ 6 & 2 \cdot 5 & + & 8 & 2 \cdot 5 & - \\ 6 & 3 & + & 8 & 3 & - \\ 6 & 3 \cdot 5 & - & 8 & 3 \cdot 5 & - \\ 6 & 4 & - & 8 & 4 & -\end{array}$

* Cells in buffer (adjusted to indicated $\mathrm{pH}$ by titration of $1 \mathrm{10}^{-2} \mathrm{M}$-phosphate buffer).

$\dagger$ 'Ionagar' titrated to indicated $\mathrm{pH}$ at $50^{\circ}$ with $\mathrm{N}-\mathrm{HCl}$.

¥ a.r.b. formed within $15 \mathrm{~min}$. after insertion of acid agar plug into capillary tube.

$+=$ formation of acid response band equivalent to control; $+-=$ weak acid response band; $-=$ no acid response band formed.

organisms when no stimulus was present. Acid response bands also were not formed with living organisms if the $\mathrm{pH}$ of the buffer was as low as 5 , or when the Ionagar plug was $\mathrm{pH} 8 \cdot 0$. It is interesting to speculate upon whether the increase in voltage necessary to 'force' the living organisms into the acid causing dispersion of the a.r.b. is related in some manner to the phenomenon of negative chemotaxis.

Influence of $p H$. The effect of $\mathrm{pH}$ of the suspending medium on a.r.b. formation is depicted in Table 3. Pseudomonas fluorescens grown at different $\mathrm{pH}$ values and resuspended in buffer of $\mathrm{pH} 7$ showed no difference in ability to form a.r.b. with acid agar plugs; an a.r.b. formed at any $\mathrm{pH}$ below $3^{\circ} \mathrm{O}$.

Chemical agents. Compounds found not to inhibit motility or a.r.b. formation were: urea, indole acetic acid, digitonin, cocaine $\mathrm{SO}_{4}$, amobarbital, eserine $\mathrm{SO}_{4}$, 'Triton', serotonin creatinine $\mathrm{SO}_{4}$, morphine $\mathrm{SO}_{4}$, chloramphenicol, and dicoumarol. Compounds which inhibited motility or a.r.b. formation were: atabrine, benzalkonium $\mathrm{Cl}$, sanguinarine $\mathrm{SO}_{4}$, pentachlorophenol, polymyxin, $n$-butanol, sodium dodecyl $\mathrm{SO}_{4}$, cetyl pyridinium $\mathrm{Cl}$, sodium barbital, strychnine $\mathrm{SO}_{4}, p$-chloromercuribenzoate, phenethyl alcohol, and tyrocidine $\mathrm{HCl}$. All concentrations employed are given in the methods section of this paper. Those compounds which at some concentration partially inhibited motility and a.r.b. formation were: potassium cyanide, bacteria $56 \%$ 
as motile as control at $2.5 \times 10^{-3} \mathrm{M}$; DL-p-fluorophenylalanine, $75 \%$ at $5.5 \times 10^{-2} \mathrm{M}$; PNPG, $94-59 \%$ at $\mathrm{I} \cdot 5$ to $3 \times 10^{-5} \mathrm{M}$; and DMSO, $90-70 \%$ at $3.12 \times 10^{-2}$ to $\mathrm{I} \cdot 25 \times 10^{-1}$ $\mathrm{M}$; however, at a I0-fold greater DMSO concentration, the motility rate was only $45.5 \%$ of the control.

Since temperature, viscosity, and $\mathrm{pH}$ variations all exerted inhibitory or stimulatory effects on motility of Pseudomonas fluorescens, any measurement, therefore, of influence on negative chemotaxis, was compromised.

The effect of variation of environmental $\mathrm{pH}$ on the a.r.b. initiated by varying the $\mathrm{pH}$ of agar plugs, did not give evidence of any conformation with Weber's Law in that $\mathrm{fla}^{+}$organisms failed to respond in a manner which indicated that the threshold response was a constant fraction of the environmental stimulus under the conditions described. It is possible that concordance under Weber's Law was not observed because: (I) motility rate is dependent upon pH (Schuetze \& Doetsch, 1967) and any threshold response was masked; and (2) the response may be to $\mathrm{pH}$ increments finer than those chosen for measurement in this series of experiments, indeed, finer than the measuring capability of the experimental system.

Since we have found that migration rate of an a.r.b. is related to factors such as hydrogen ion concentration, degree of ionization of the acid, and ionic strength of the buffer, including that to which the chemical agents have been added, it is desirable that any compound which inhibits or stimulates the chemotactic reaction manifests itself by preventing or intensifying band formation. At the same time, such an agent ought to exhibit little effect on motility rate, particularly if motility per se and chemotactic responses are distinct as found by Adler (1966a) in the case of Escherichia coli.

The difficulty of 'proving' inhibition of chemotaxis lies in the technical difficulty of demonstrating that motility is not affected at the same time that chemotaxis is repressed. Measurement of motility by crude visual methods has several shortcomings, but it seems the most feasible preliminary method available. The motility rate in control organisms is not initially stable, and varies considerably, so that one must allow the suspension to stand for Io min. after preparation; care also must be taken to wait at least one min. before counting any slide preparation, since motility rate again stabilizes after this time.

Failure to observe inhibitory effects of chemical agents on negative chemotaxis may have several explanations: (1) inhibitory agents exist but were not found; (2) both motility and chemotaxis were simultaneously affected; (3) the action of agents was not observable under the conditions imposed in the experiment; and (4) the agents did not gain access to the membrane or postulated receptors.

The idea of hydrogen ions acting as a stimulus in a negative chemotactic reaction in the organism studied is appealing when viewed in the light of possible alteration of electrical potentials along the membrane. The theoretical number of hydrogen ions 'displaced' by the volume of one Pseudomonas fluorescens cell $\left(0.96 \mu^{3}\right)$ at pH 5.5 is $2 \times 10^{3}$ or one $\mathrm{H}^{+}$for a $\mathrm{I} \mathrm{m} \mu$ thick cross-section of the organism. It is interesting to speculate as to whether this is, in fact, the 'signal' to which this organism responds.

Mechanisms which control flagellar responses of bacteria remain, as yet, unknown. Any 'neurological' system, however primitive, described in flagellated eucaryotic organisms seems completely lacking in procaryotic forms; in addition, the exact 
nature of excitations (if any) elicited by stimuli also is unknown (Doetsch \& Hageage, 1968).

A theory developed by us, in the course of laboratory experiences with various flagellated bacteria (Doetsch, 1966 b; Doetsch, Cook \& Vaituzis, 1967) suggested that the flagellum or flagellar fascicle is part of an excito-motor system developed for spacial accommodation. Stimuli are considered to be 'sensed' by the cytoplasmic membrane acting as a 'monitor' or signal receptor. The entire membrane may serve this function, or possibly there are specialized receptor areas which may or may not lie near the origin or point of insertion of the flagellum (Doetsch, 1966a). The mechanism of sensing environmental stimuli is visualized as involving an induced change in membrane potential by which means the signal is transduced and transmitted to a 'motor unit' (possibly a differentiated membrane immediately surrounding the flagellum). A gap, synapse, or an equivalent thereof, and a primitive 'muscle-membrane' or contractile element, may be coupled with, and activate, a rigid or semirigid non-contractile flagellum. The chemical events may be similar to those found in higher animals, based upon acetylcholine (Doetsch \& Hageage, 1968).

Successful experiments influencing and interfering with the postulated sensing. function of the membrane would add considerable support to this view of the nature of sensory processes in bacteria. The response may be, on the other hand, a result of some change, induced by the stimulus, in the general metabolic state of the organism, and controlled by a mechanism which is linked to one or several energy-yielding. pathways. This possibility has yet to be ruled out in the phenomenon of negative chemotactic responses.

Studies with bacterial systems might yield valuable clues into the general problem of how the energy of stimuli is transduced into the language of the sensory code at the unicellular level. The implications of such studies are exciting to contemplate and undoubtedly would open new horizons for development of a theory of bacterial behaviour and motility.

The authors wish to express appreciation to $\mathrm{Dr}$ B. S. Roberson for aid and advice with the electrophoretic experiments and to $\mathrm{Mr} \mathrm{Z}$. Vaituzis for photographic work. This research was supported in part by a grant (AI 07835-0I) from the United States Public Health Service.

\section{REFERENCES}

ADLER, J. (1966a). Effect of amino acids and oxygen on chemotaxis in Escherichia coli. J. Bact. 92, I2I.

ADLER, J. (1966b). Chemotaxis in bacteria. Science, N.Y. 153, 708.

Armstrong, J. B., Adler, J. \& DAHL, M. M. (1967). Non-chemotactic mutants of Escherichia coli. J. Bact. 93, 390.

Baracchini, O. \& Sherris, J. C. (1959). The chemotactic effect of oxygen on bacteria. J. Path. Bact. 77, 565 .

BeiJerInCK, M. W. (I893). Über atmungsfiguren beweglichen Bakterien. Zentbl. Bakt. ParasitKde. (Abt I) I4, 827.

Brinton, C. C. (1959). Non-flagellar appendages of bacteria. Nature, Lond. r83, 782.

Carlson, F. D. (1962). A theory of the survival value of motility. In Spermatozoan Motility, ed. D. W. Bishop. AAAS Pub. no. 72. Washington, D.C.

Clayton, R. K. (1958). On the interplay of environmental factors affecting taxis and motility in Rhodospirillum rubrum. Arch. Mikrobiol. 29, 189.

DOETSCH, R. N. (1966a). Some speculations accounting for the movement of bacterial flagella. J. theor. Biol. I1, 411 . 
DoETsCH, R. N. (1966b). Notes on some structural features of Sphaerotilus natans. Arch. Mikrobiol. $54,46$.

DoETSCH, R. N. \& HAGEAGE, G. J. (1968), Motility in procaryotic organisms; problems, points of view, and perspectives. Biol. Rev. 43, 317.

Doetsch, R. N., CoOK, T. M. \& VAITUZIS, Z. (1967). On the uniqueness of the flagellum of Thiobacillus thiooxidans. Antonie Van Leeuwenhoek. 33, 196.

EngelmanN, T. W. (1883). Ein Beitrag zur vergleichen Physiologie des licht- und farbensinnes Bacterium photometricum. Pflügers Arch. ges. Physiol. 30, 95.

LINKs, J. (1955). I. Een hypothese over het mechanisme van de (phobo-) chemotaxis. II. De carotenoiden, steroiden en vetzuren van Polytoma uvella. Dissertation, Leiden.

RHodes, M. E. (1958). The cytology of Pseudomonas as revealed by a silver-plating staining method. J. gen. Microbiol. 18, 639.

SCHUETZE, P. \& DoETSCH, R. N. (1967). Reversible paralysis of the flagella of certain Gram-negative bacteria. Can. J. Microbiol. 13, II 4.

SHOESMITH, J. G. (I960). The measurement of bacterial motility. J. gen. Microbiol. 22, 528.

SMrTH, J. L. \& DOETSCH, R. N. (1968). Motility in Pseudomonas fluorescens with special reference to survival advantage and negative chemotaxis. Life Sci. 7, 875 .

Wright, A. E. \& ColebrooK, L. (1921). Technique of the Teat and Capillary Tube, p. 22. London: Constable.

\section{EXPLANATION OF PLATE}

Photomicrograph of an acid response band $(\times 290)$; stimulus is on the left 

Journal of General Microbiology, Vol. 55, No. 3

Plate I

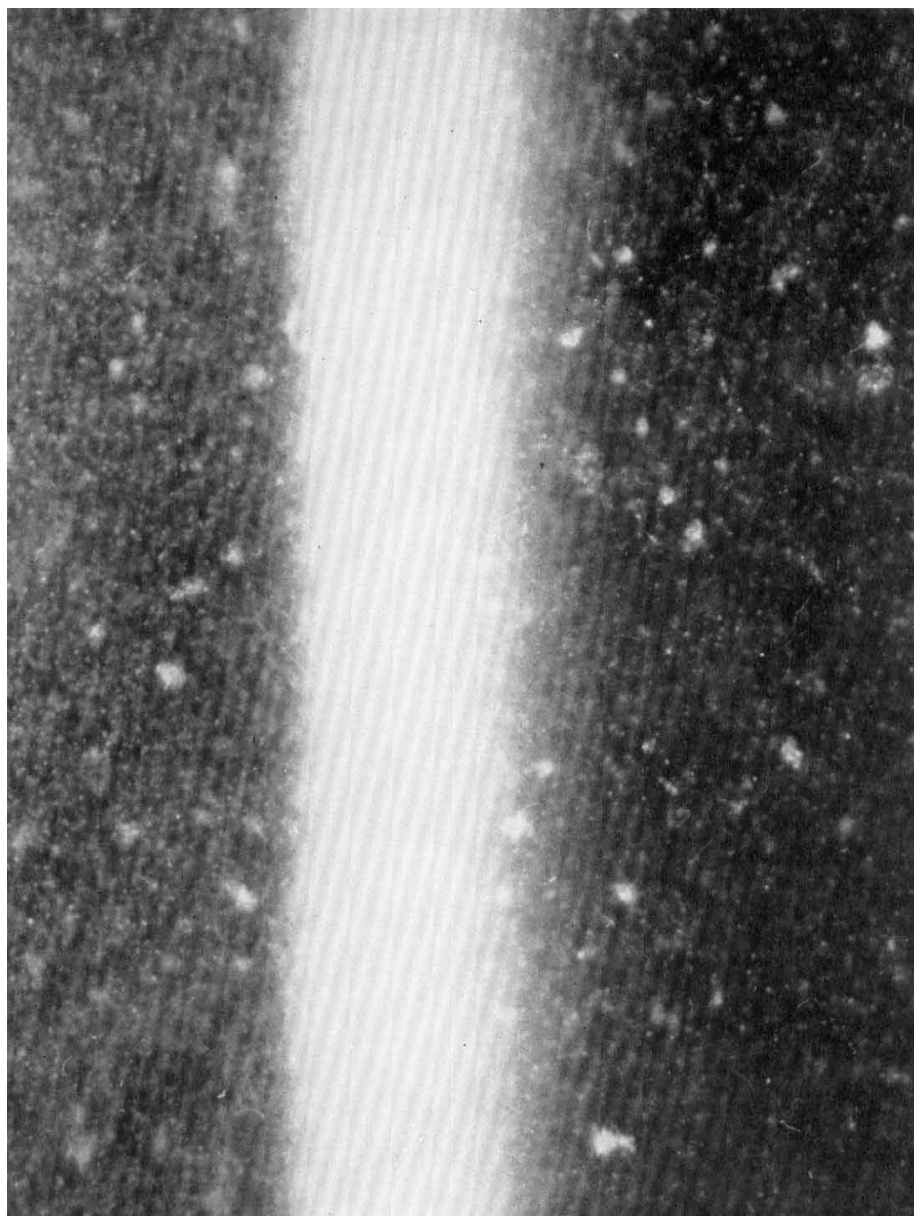

